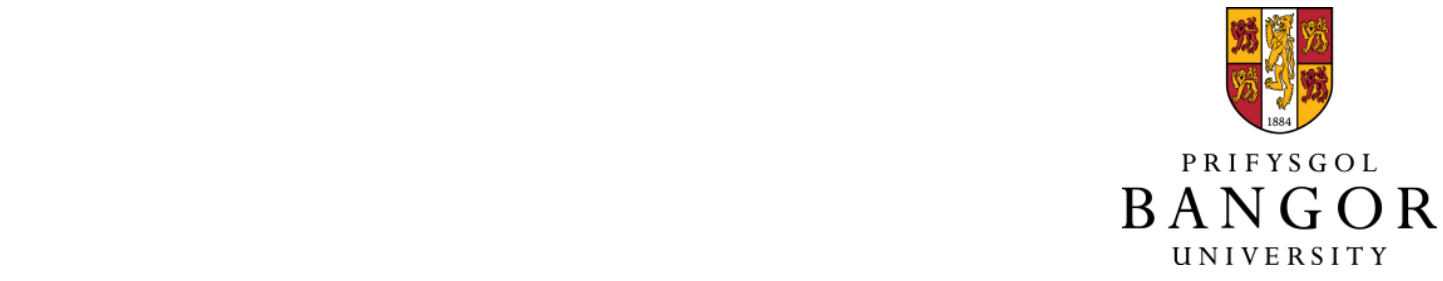

Woody litter protects peat carbon stocks during drought

Fenner, Nathalie; Freeman, Chris

Nature Climate Change

DOI:

10.1038/s41558-020-0727-y

Published: 16/03/2020

Peer reviewed version

Cyswllt i'r cyhoeddiad / Link to publication

Dyfyniad o'r fersiwn a gyhoeddwyd / Citation for published version (APA):

Fenner, N., \& Freeman, C. (2020). Woody litter protects peat carbon stocks during drought.

Nature Climate Change, 10(4), 363-369. https://doi.org/10.1038/s41558-020-0727-y

\footnotetext{
Hawliau Cyffredinol / General rights

Copyright and moral rights for the publications made accessible in the public portal are retained by the authors and/or other copyright owners and it is a condition of accessing publications that users recognise and abide by the legal requirements associated with these rights.

- Users may download and print one copy of any publication from the public portal for the purpose of private study or research.

- You may not further distribute the material or use it for any profit-making activity or commercial gain

- You may freely distribute the URL identifying the publication in the public portal ?
}

Take down policy

If you believe that this document breaches copyright please contact us providing details, and we will remove access to the work immediately and investigate your claim. 


\title{
Woody litter protects peat carbon stocks during drought
}

\author{
Nathalie Fenner ${ }^{\circledR} \otimes$ and Chris Freeman $(\mathbb{C}$
}

\begin{abstract}
Northern peatlands store $\mathbf{3 0}$ No of the world's soil carbon. This carbon sequestration is due to slow decomposition, as illustrated by ancient wooden artefacts and 'bog bodies' preserved over millennia. Such artefacts suggest that carbon could be captured externally and stored long term in peat. However, whether such carbon would remain stable following lowered water tables is not known. Here we show that adding woody litter results in preservation of the exogenous carbon, as well as protection of soil carbon within the host ecosystem from severe drought, as a result of leached polyphenolics. These compounds not only inhibit microbial extracellular and intracellular metabolism but also deprive microbial growth of iron and substrates such as carbon and nitrogen. Our results suggest that this technique harnesses natural ecosystem resilience mechanisms and may have implications for new carbon-farming approaches.
\end{abstract}

$\mathrm{N}$ orthern peatlands store around $250-450 \mathrm{Pg}$ of carbon $^{1,2}$ and contribute to cooling the planet ${ }^{2,3}$. Afforestation has long been recognized as a valuable tool for countering the buildup of atmospheric $\mathrm{CO}_{2}{ }^{4-6}$, for example, offsetting an estimated $11 \%$ of annual GHG emissions in the United States ${ }^{5}$. Forests store around $861 \mathrm{PgC}$ (refs. ${ }^{4,67}$ ), with net ecosystem production generally considered to be high ${ }^{4-6,8}$. Soil stocks account for $44 \%$, live biomass $42 \%$, deadwood $8 \%$ and litter $5 \%$ (ref. ${ }^{6}$ ). The latter live and dead compartments are vulnerable to re-release when trees die and decompose or are subject to pests, diseases, deforestation and forest fires ${ }^{4-6,8}$. However, unlike forests, peatlands are unusually effective at preventing re-release of stored carbon to the atmosphere? Traditionally, this is attributed to slow decomposition rates in relation to production rates as a result of waterlogging, low $\mathrm{pH}$ and cool conditions ${ }^{1,2,9,10}$. Sphagnum peatlands were found to possess a particularly effective mechanism for restricting enzymic decomposition ${ }^{9}$ whereby oxygen constraints associated with waterlogging suppress the activity of phenol oxidase enzymes. This, in turn, allows an accumulation of enzyme-inhibiting phenolic compounds to impede the activity of the major agents of nutrient cycling and decomposition, namely, hydrolase enzymes'. This 'enzymic latch' was later found to sit within a biogeochemical cascade whereby multiple constraints were preventing decomposition, rather than just waterlogging, but severe drought could disrupt this by accelerating nutrient cycling and raising $\mathrm{pH}^{11}$.

Combining forest carbon capture with peatland preservation to improve carbon sequestration has been proposed ${ }^{12}$ but never tested, and whether the approach is vulnerable to release of carbon in gaseous or dissolved form ${ }^{1,3,13}$ during increasing drought events ${ }^{7}$ remains unknown. Thus, we investigated the stability of woody litter in peatland ecosystems and the impact of lowered water tables (due to drainage or drought) on peatland decomposition. Our results suggest not only that the woody material is effectively preserved vo but that the extra soluble polyphenols that the wood leaches inhibit both extracellular and intracellular metabolism and deprive microbial growth of both iron and substrates. This further limits decomposition, protecting the host ecosystem carbon stock, even during severe drought. Such findings held true across successional stages and water table regimes, which have been proposed to account for differences in sensitivity to drought ${ }^{14}$ and further our understanding of how wooded peatlands can exist under intermittently dry conditions. In addition, these findings suggest new mechanisms that harness natural ecosystem resilience mechanisms, with applications in geological and ecological engineering to protect carbon stocks and increase sequestration in pristine drought-sensitive systems through to highly degraded drought-resistant systems.

\section{Determining the stability of exogenous carbon in peat}

Initial studies investigated whether peat could stabilize exogenous carbon captured as wood, that is, whether inserted wood decomposed at a slower rate than exposed wood. For this, we used an in vitro standard biodegradation approach with durable oak (Quercus robur) and non-durable poplar (Liriodendron tulipifera), as defined by percentage mass loss $\mathrm{s}^{15}$. Wood remaining on the surface of the peat showed an average mass loss of $49 \% \mathrm{y}^{-1}$ (oak) and $73 \% \mathrm{y}^{-1}$ (poplar), while timber inserted $5 \mathrm{~cm}$ below the peat's surface lost only $12 \% \mathrm{y}^{-1}$ and $18 \% \mathrm{y}^{-1}$, respectively, under waterlogged (anaerobic) conditions, confirming that insertion preserved exogenous carbon.

This was followed by incubating wood inserted into Sphagnum peat (site 1, Supplementary Table 1) under anaerobic, aerobic, anaerobic conditions in sequence to determine whether the exogenous carbon was resilient to changes in redox potential, that is, whether drainage or drought would increase mass loss, as would be expected from traditional and enzymic-latch theories. Surprisingly, no increase in mass loss was found, compared with the waterlogged control, suggesting the carbon was stabilized within the peat regardless of oxygen status. Furthermore, there was an increase in soluble polyphenolics (oak: $0.5 \mathrm{mgl}^{-1}, 36 \%$; poplar: $0.4 \mathrm{mgl}^{-1}, 24 \%$ ). A reduction in global warming potential (GWP) was also found (oak 173\%; poplar $72 \%$ ). Oak was particularly effective, shifting the peat from a source of $183 \mathrm{mg} \mathrm{CO}$-equivalent $\left(\mathrm{CO}_{2} \mathrm{e}\right) \mathrm{m}^{-2} \mathrm{~h}^{-1}$ to a sink of $251 \mathrm{mgCO}_{2} \mathrm{e} \mathrm{m}^{-2} \mathrm{~h}^{-1}$ (Fig. la), suggesting not only suppressed decomposition (that is, a reduction in source strength) but also uptake of GHGs (that is, 'scrubbing' from the atmosphere). While variation was relatively high, $\mathrm{N}_{2} \mathrm{O}$ contributions shifted from a source of $5.54 \pm 6.14 \mathrm{mgCO}_{2} \mathrm{e} \mathrm{m}^{-2} \mathrm{~h}^{-1}$ to a sink of $-14.95 \pm 17.22 \mathrm{mg} \mathrm{CO}_{2} \mathrm{e} \mathrm{m}^{-2} \mathrm{~h}^{-1}$ and showed the largest percentage 
a

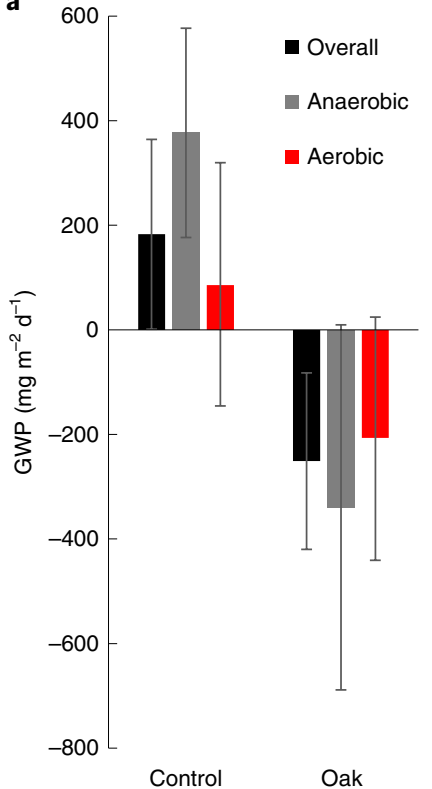

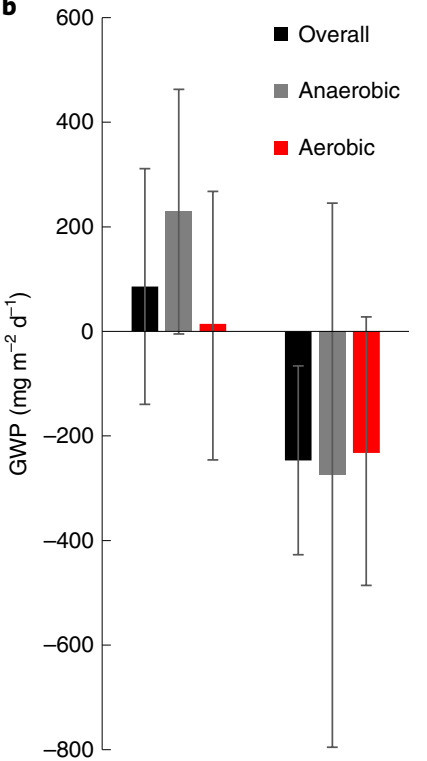

Fig. 1 | Effect of changes in redox potential on GHG fluxes from ombrotrophic peat. $\mathbf{a}, \mathbf{b}, \mathrm{GWP} \mathrm{CO}_{2} \mathrm{e}$ of GHGs from in vitro microcosms containing durable oak (a) and non-durable poplar (b) overall (that is, the duration of the anaerobic-aerobic-anaerobic $60 \mathrm{~d}$ incubation) and when exposed to anaerobic and aerobic conditions. Oak was significantly different from the control (overall paired $T=-3.66, P=0.006$ ) with a $341 \%$ and $190 \%$ reduction under aerobic and anaerobic conditions, respectively. Poplar showed a large reduction under aerobic and anaerobic conditions ( $1,388 \%$ and $220 \%$, respectively) but was more variable (overall paired $T=-1.36, P=0.211)$. Negative fluxes represent uptake from the atmosphere. $N=6$ microcosms per treatment; error bars denote SEM.

change $(370 \%)$ with oak addition, suggesting the potential for large effects on GWP. Similar patterns were found for poplar but with more variation (Fig. 1b). However, suppression was greatest during the aerobic phase compared with the anaerobic phase for both wood types (Fig. 1a,b).

The experiment suggests that the durable wood induces stronger constraints on decomposition than the non-durable wood and that the threat of carbon loss due to a drought-induced destablization of the enzymic latch is much reduced, even in these predominantly waterlogged and therefore drought-sensitive ${ }^{14}$ systems. Furthermore, adding phenol oxidase enzymes to further test the threat to carbon stocks posed by a temperature- or nutrient-mediated opening of the latch ${ }^{11}$ when exposed to the simulated drought did not increase mass loss, suggesting 'excess' inhibiting capacity or resilience.

\section{Effects of peat type on exogenous carbon stability}

Wood was then inserted $(5 \mathrm{~cm}$ depth) into intact plant-peat mesocosms, representing more-natural conditions than the previous experiment, by including natural peat profiles and microsites. These were collected from a range of peatland types (Supplementary Table 1) across four trophic statuses (ombrotrophic, oligotrophic, mesotrophic and eutrophic) because nutrients and $\mathrm{pH}$ drive decomposition $^{11}$, with nitrogen levels being inversely correlated with phenolics in bogs ${ }^{16}$. However, it should be noted that the range of trophic status includes co-varying physicochemical variables such as nutrients, $\mathrm{pH}$ and organic matter. The exogenous carbon was again stabilized, with poplar losing only $1.2 \% \mathrm{y}^{-1}\left(0.14 \mathrm{gy}^{-1}\right)$ of its mass in the ombrotrophic system, $1.4 \% \mathrm{y}^{-1}\left(0.15 \mathrm{~g} \mathrm{y}^{-1}\right)$ in the oligotrophic system and $1.9 \% \mathrm{y}^{-1}\left(0.22 \mathrm{~g}^{-1}\right)$ in the mesotrophic system. However,
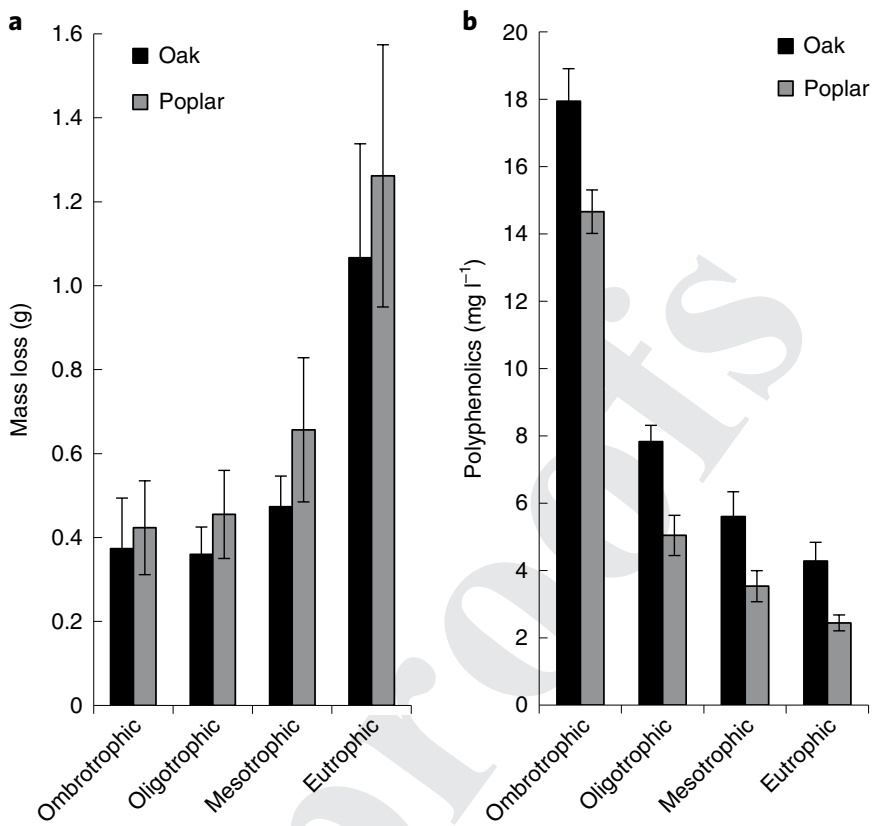

Fig. 2 | Effect of peat type on wood preservation and polyphenolic accumulation. a,b, Oak and poplar mass loss (a) and soluble polyphenolics concentration (b) after addition to a range of peatland types over $3 \mathrm{yr}$, including simulated 1 per $100 \mathrm{yr}$ drought ( 60 d duration, water table $30 \mathrm{~cm}$ below surface). Mass loss was strongly related to trophic status (oak: $R^{2}=40.93, T=6.82, P=0.000$; poplar: $\left.R^{2}=36.15, T=6.23, P=0.000\right)$ as was polyphenolic concentration (oak: $R^{2}=91.95, T=6.03, P=0.000$; poplar: $\left.R^{2}=94.74, T=4.78, P=0.000\right) . N=6$ plant-peat mesocosms per trophic level per treatment; error bars denote SEM.

oak again was more resistant, losing $1 \% \mathrm{y}^{-1}\left(0.12 \mathrm{gy}^{-1}\right), 1.1 \% \mathrm{y}^{-1}$ $\left(0.12 \mathrm{gy}^{-1}\right)$ and $1.4 \% \mathrm{y}^{-1}\left(0.16 \mathrm{y}^{-1}\right)$, respectively (Fig. 2a). As with the in vitro results, polyphenolics concentrations increased with wood additions, and this was true for both wood types across all peatlands. Oak showed higher polyphenolics concentrations (Fig. 2b) though, suggesting wood type, and therefore leachate character, is probably important in determining microbial decomposition.

Thus, ombrotrophic bogs were the most effective exogenous carbon preservation systems, showing the lowest mass loss and highest accumulation of polyphenolics (Fig. 2a,b), consistent with their exceptionally slow decomposition rates (attributed to low $\mathrm{pH}$, high polyphenolics ${ }^{17}$ and unusual tanning properties, which make nitrogen unavailable ${ }^{18}$ ). However, mass loss in the oligotrophic and mesotrophic sites showed no substantial difference from the ombrotrophic system (Fig. 2a), and even in the eutrophic system there was an accumulation of polyphenolics and low mass loss rates for both oak $\left(3.1 \% \mathrm{y}^{-1}, 0.36 \mathrm{gy}^{-1}\right)$ and poplar $\left(4.1 \% \mathrm{y}^{-1}, 0.42 \mathrm{gy}^{-1}\right)$. The latter was supported by natural alluvial recruitment of coarse woody debris and preserved archaeological relicts ${ }^{19}$. It should be noted, however, that these systems are still relatively nutrient-poor (Supplementary Table 1), and both woods became more vulnerable to decay with increasing trophic status (Fig. 2a).

Focussing on oak, due to its higher polyphenolics concentrations, the flux of all GHG species was reduced (Supplementary Fig. 1a,b and Fig. 3a), leading to decreased GWP across all systems (Fig. 3b). The greatest percentage change was found in the ombrotrophic system (35\%), which also showed the strongest $\mathrm{N}_{2} \mathrm{O}$ reduction, acting as a sink overall (Fig. 3c). Simulated drought, following $2 \mathrm{yr}$ of waterlogged conditions, further enhanced this effect in the ombrotrophic, oligotrophic and mesotrophic systems (Fig. 3a,b and Supplementary Fig. 1c,d), with $\mathrm{N}_{2} \mathrm{O}$ contributions particularly 

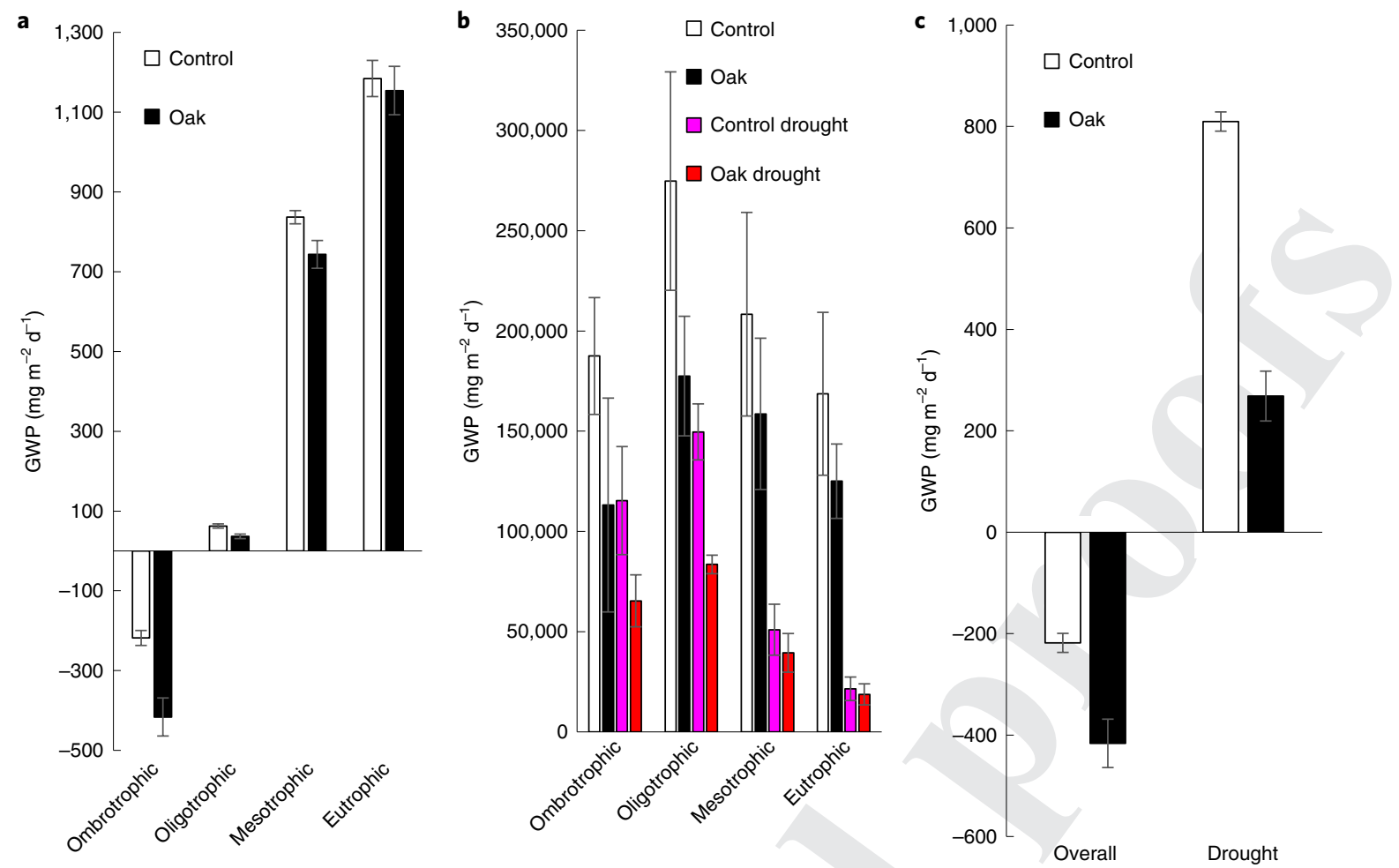

Fig. 3 Effect of oak addition on GHG fluxes across peat types. $\mathbf{a}, \mathrm{N}_{2} \mathrm{O}$ contributions to GWP (in $\mathrm{CO}_{2} \mathrm{e}$ ) after oak addition compared with controls across a range of peatland types over $3 \mathrm{yr}$, including simulated 1 per $100 \mathrm{yr}$ severe drought ( 60 d duration, water table $30 \mathrm{~cm}$ below surface). b, Total GWP over $3 \mathrm{yr}$ for control and oak-supplemented peat and showing greater effects in drought. Overall percentage suppression due to oak: ombrotrophic, 35\%; oligotrophic, 31\%; mesotrophic, 19\%; eutrophic, $18 \%$. Drought suppression due to oak: ombrotrophic, 38\% ( $T=3.30, P=0.021)$; oligotrophic, 34\% ( $T=5.03, P=0.004)$; mesotrophic, $23 \%$ and eutrophic, $13 \%$. c , $\mathrm{N}_{2} \mathrm{O}$ contributions to GWP after oak addition compared with controls in ombrotrophic peat (overall, $198 \%$ reduction: paired $T=4.29, P=0.008$; severe drought, $67 \%$ reduction: $T=10.78, P=0.000$ ). Negative fluxes represent uptake from the atmosphere. The ombrotrophic site was found to be a net sink when averaged overall (Supplementary Text 1 ) but a source during drought. $N=6$ plant-peat mesocosms per trophic level per treatment; error bars denote SEM.

inhibited in ombrotrophic systems (Fig. 3a and Supplementary Fig. 1d), consistent with in vitro results.

While $\mathrm{CO}_{2}$ and $\mathrm{CH}_{4}$ contribute more to GWP, $\mathrm{N}_{2} \mathrm{O}$ is most affected by supplementation (Supplementary Fig. 1, Fig. 3 and Supplementary Text 1). Given that drainage releases $\mathrm{N}_{2} \mathrm{O}$, altering peatlands globally from a net sink to a source of $\mathrm{GHG}^{20}$, and that emissions from tropical and drained peatlands are likely being underestimated ${ }^{21}$, such a property could be invaluable.

Similarly, we also measured dissolved organic carbon (DOC) and dissolved organic nitrogen (DON) concentrations leaching from the peat as intermediates of decomposition available for export to receiving waters with the potential to reduce drinking water quality or act as substrates for further GHG production ${ }^{22,23}$. DOC concentrations fell significantly $\left(24 \%, 18 \mathrm{mgl}^{-1}\right)$ over $3 \mathrm{yr}$ and $28 \%\left(16 \mathrm{mgl}^{-1}\right)$ in severe drought, with polyphenolics concentrations increasing by $26 \%\left(3.8 \mathrm{mgl}^{-1}\right)$ and $59 \%\left(5.0 \mathrm{mgl}^{-1}\right)$ within this pool, respectively, giving an increased polyphenolics-to-DOC ratio, thought to be more important in limiting microbial metabolism than high concentrations of polyphenolics alone ${ }^{24}$. DON showed a similar pattern (36\% overall, $59 \%$ during severe drought, Supplementary Table 2). In addition, an illustration of the extent of the impact of polyphenolics on decomposition can be seen in shifts in the isotopic signatures of these intermediates (Supplementary Text 1 and Supplementary Fig. 2).

\section{Pre-aged oak}

The preceding wood mass loss rates are calculated from short-term experiments and, as such, may be faster than long-term averages due to preferential decomposition of labile organic matter. However, conversely, polyphenolic extractive concentration may decline with time, through leaching, which can reduce durability in some spe$\operatorname{cies}^{15}$. Thus, we investigated the rates of loss for pre-aged oak, which had been naturally decomposing where it fell for $>5 \mathrm{yr}$. Exposed oak lost $9 \% \mathrm{y}^{-1}\left(0.90 \mathrm{~g} \mathrm{y}^{-1}\right)$ of its mass, compared with $1 \% \mathrm{y}^{-1}\left(0.13 \mathrm{gy}^{-1}\right)$ for that inserted into mesotrophic peat (Fig. 4a). For the non-aged oak inserted into the same peat type (Fig. 2a), the rate of loss is also $1 \% \mathrm{y}^{-1}\left(0.16 \mathrm{~g} \mathrm{y}^{-1}\right)$, suggesting that peat preserves oak irrespective of age. Pre-aged oak also significantly reduced GWP, even during drought (Fig. 4b), suggesting that protective effects on the host peat carbon stock are likely to last in the medium to long term.

\section{Hydrological legacy}

Evidence suggests that long-term hydrological regime affects the response of peatlands to drought ${ }^{11}$ via the kinetics of phenolic inhibition ${ }^{25}$. Therefore, we tested whether wood supplements had the same effect using peat from a 'natural laboratory', which included four hydrological regimes (or drought sensitivities ${ }^{14}$ ): waterlogged pristine, increased moderate drought frequency, drainage, and drainage with rewetting. Overall, there was a $50 \%$ difference due to oak addition for the pristine peat (Fig. 5a), with GWP in the drought phase under wood treatment being similar to the control under waterlogged conditions. In the case of $\mathrm{N}_{2} \mathrm{O}$ contributions, these shifted from a source to a sink because of wood supplements. Similar effects were seen for the moderate drought site $(41 \%, P=0.05)$, and while the drained and rewetted sites showed a lower magnitude of effect, this was still substantial $(25 \%, P=0.001$ 

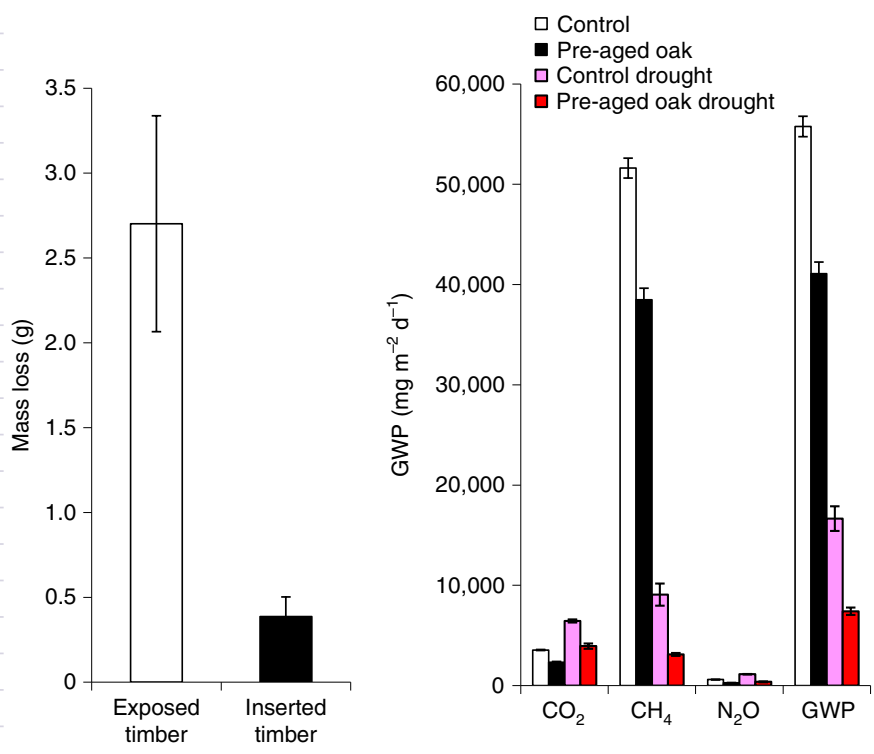

Fig. 4 | Preservation of pre-aged oak in peat and its effect on GHG fluxes. $\mathbf{a}, \mathbf{b}$, Effects of inserting pre-aged oak into mesotrophic peat over $3 \mathrm{yr}$ on mass loss ( $86 \%$ reduction compared with exposed wood, $T=3.69$, $P=0.014)$ (a) and contributions of GHG species to GWP $\left(\left(\mathrm{CO}_{2} \mathrm{e}\right) 26 \%\right.$ reduction: $T=11.28, P=0.000)$ ) and showing greater effect of wood in drought (simulated 1 per 100 yr severe drought, $60 \mathrm{~d}$ duration, water table $30 \mathrm{~cm}$ below surface) compared with the control (55\%, $T=7.46, P=0.001)$ (b). $N=6$ mesotrophic plant-peat mesocosms; error bars denote SEM.

and $30 \%, P=0.005$, respectively), suggesting that the treatment also could benefit degraded and restored peatlands, irrespective of hydrological legacy.

\section{Naturally wooded systems}

If leached wood polyphenolics protect the host peat carbon stock against drought effects, then naturally shrubby or forested peatlands might be expected to be particularly resistant to drought. Recent evidence from US Pocosin systems supports this, suggesting that these systems can exist with unusually low water tables due to an accumulation of polyphenolics from woody shrubs over millennia $^{14}$. Thus, we investigated the effect of a shift from SphagnumJuncus communities to woody shrubs (Erica and Calluna) as a result of drainage in an upland UK system. Leachable polyphenolic levels increased (31\%, Fig. 5b) despite a relatively short period of effect and mixed plant community composition ( $20 \%$ shrubs), in line with findings that polyphenolics increase with the expansion of shrubs in European peat ${ }^{26}$. A 1 per $100 \mathrm{yr}$ natural drought also increased polyphenolics in both systems (Fig. 5b), in line with complex limitations on decomposition, rather than just oxygen ${ }^{14,27,28}$, such as moisture stress, $\mathrm{pH}^{11,28,29}$ and litter type ${ }^{28,29}$. A large and significant GWP saving was also found under the shrubby peatland systems here (Fig. 5c), suggesting there is a protection mechanism preventing carbon stocks from disappearing as $\mathrm{CO}_{2}$. Indeed, Laiho et $\mathrm{al}^{28}$, working on Scots pine (Pinus sylvestris) litter, found that long-term forestry drainage does not increase decomposition of fresh organic matter, and moderate drainage actually increased carbon sequestration in alder carr peatlands ${ }^{30}$.

\section{Mechanisms inhibiting decomposition}

Four non-mutually exclusive mechanisms are proposed to account for the antimicrobial properties of polyphenolics (particularly tannins) in the literature: (1) inhibition of extracellular enzyme activities, (2) deprivation of substrates required for growth, (3) direct inhibition of microbial metabolism and (4) iron deprivation ${ }^{31-33}$.

\section{Inhibition of extracellular enzyme activities}

A suppression of all extracellular enzymes activities involved in carbon and nitrogen cycles was observed (Supplementary Table 2 and Supplementary Text 2), consistent with the main mechanism of antimicrobial action proposed in the literature, that is, inactivation via protein precipitation and competitive inhibition ${ }^{24,31-34}$. In line with the increased effect on decomposition during drought, the majority of enzymes were suppressed to a greater degree. Extracellular phenol oxidase showed the largest inhibition, 58\% during drought ( $33 \%$ overall) with NAGase being inhibited by $52 \%$ under drought, the latter showing the largest inhibition of all the biological indices measured overall (47\%).

\section{Deprivation of substrates required for growth}

In addition to DOC (Supplementary Table 2), DON concentrations in the pore waters were particularly affected $(-36 \%, P=0.044)$, and polyphenolics have been reported to protect polymeric substrates from decomposition more efficiently via complexation mechanisms than those of low molecular weight (for example, peptides and amino acids) due to differences in affinity ${ }^{32}$. However, ammonium was also significantly reduced (17\%). Given the particularly low inorganic nutrient concentrations in ombrotrophic peatland systems (Supplementary Tables 1 and 2), where DON is likely to be a major $\mathrm{N}$ source for microbial growth ${ }^{35}$, this may explain the particularly efficient sequestration and protection of host ecosystem soil carbon in such bogs, especially when combined with tanning effects ${ }^{18}$. The potential for reduced primary production in the long term as a result of supplementation requires further research (Supplementary Text 2).

\section{Direct effects on microbial metabolism}

Intracellular indices were also inhibited, suggesting that polyphenolics are acting on microbial metabolism directly (for example, through oxidative phosphorylation ${ }^{32}$ ). Bacterial growth rates were $37 \%$ lower and intracellular C23O (catechol 2,3-dioxygenase, a key enzyme in lignin degradation ${ }^{13}$ ) activities were inhibited by $40 \%$ overall (Supplementary Table 2).

\section{Iron deprivation}

Wood treatments appeared to induce iron deficiency with concentrations being lowered by $28 \%$ overall (Supplementary Table 2). In nutrient-poor wetlands, ferrous iron $\left(\mathrm{Fe}^{2+}\right)$ has long been known to stimulate decomposition ${ }^{36}$. Many types of phenol oxidases synthesised by both bacteria and fungi contain $\mathrm{Fe}^{2+}$ in their haem complex, and this, together with $\mathrm{H}_{2} \mathrm{O}_{2}$, generates $\mathrm{OH}$ radicals representing a strong polyphenolic oxidizing agent, particularly in drought conditions (known as the Fenton reaction) ${ }^{36}$. Tannin has also been reported to bind manganese, which is also used in certain phenol oxidases, with oxidation of $\mathrm{Mn}^{2+}$ forming $\mathrm{H}_{2} \mathrm{O}_{2}$ and, hence, strongly catalysing oxidation of phenolics ${ }^{36}$. Thus, polyphenolics apparently have broad 'metal scavenging' effects, potentially inhibiting both intracellular and extracellular metabolism.

\section{Protection of host ecosystem soil carbon during drought}

The preceding evidence suggests that all four mechanisms are contributing to the inhibitory effect of wood treatments. These mechanisms are likely to be inextricably linked, rather than additive, and we discuss this as a 'quadruple lock' on peat decomposition. For example, inhibited extracellular enzymes would lead to deprivation of substrates required for microbial growth, and direct effects on microbial metabolism could reduce de novo enzyme synthesis, reducing nutrient acquisition further. If we assume that abundance of microbes is an integrated measure of inhibitory effects on all metabolic pathways, this also suggests suppression (20\% across morphotypes (for example, cocci (spherical-shaped 

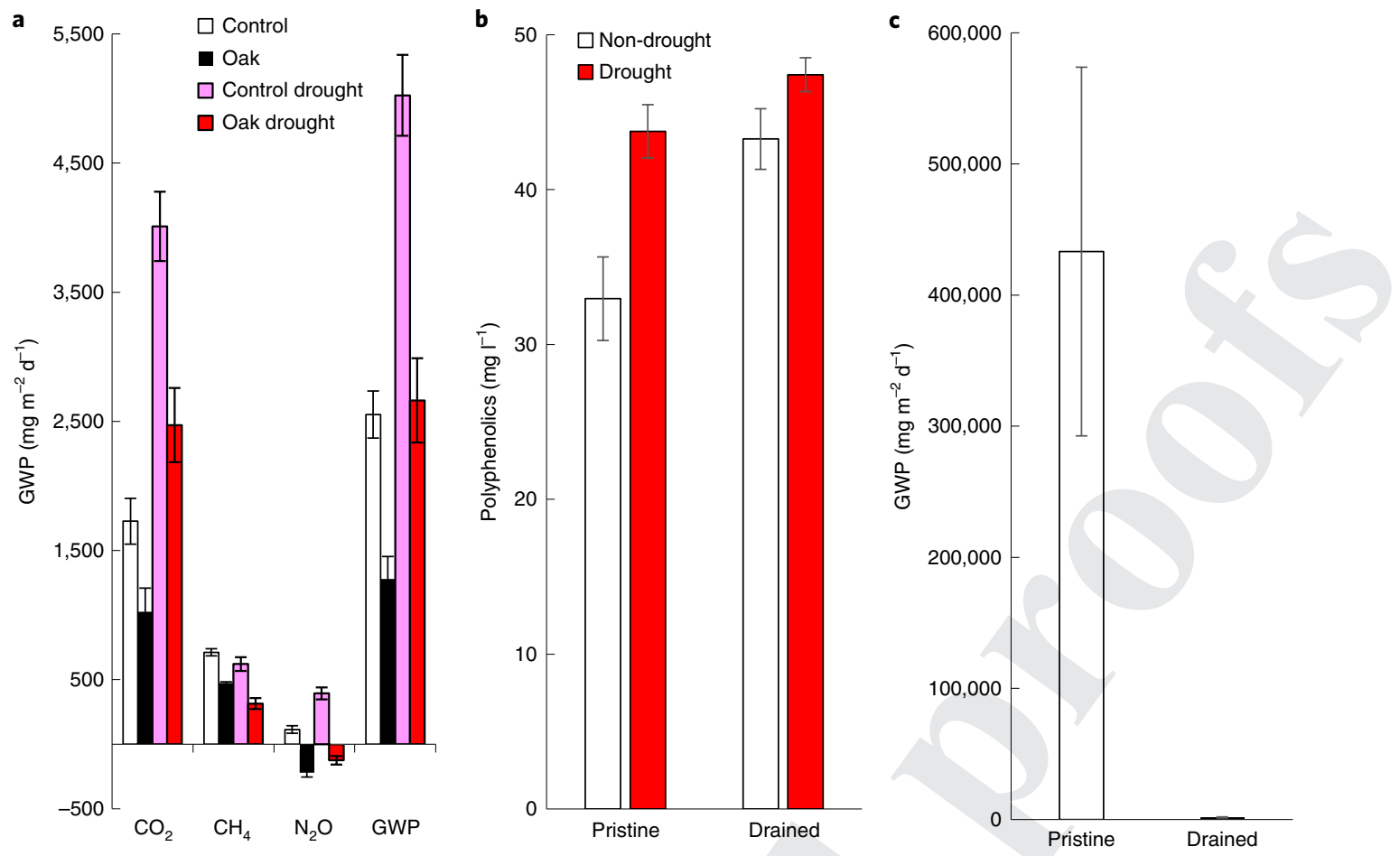

Fig. 5 | Oak additions reduce the impacts of drought and drainage on peatland carbon losses. a, Effects of in situ oak supplementation within oligotrophic pristine peat on GHG species contributions to GWP over $3 \mathrm{yr}$ and during drought (simulated 1 per $100 \mathrm{yr}$ severe drought, $60 \mathrm{~d}$ duration, water table $30 \mathrm{~cm}$ below surface). Overall, there was a 50\% difference and in the drought phase $47 \%(T=6.89, P=0.001$ and $T=5.40, P=0.003$, respectively) due to treatment. b. Comparison of pristine (waterlogged Sphagnum-dominated) and drained (shrubby) peatland leachable polyphenolics before and after the 2006 severe natural drought (1 per $100 \mathrm{yr}$ ), showing higher levels of polyphenolics in the drained site and as a result of drought in both systems. Before drought, concentrations were 31.3\% higher in the drained site $(T=-3.39, P=0.043)$; for the severe drought year, there was an $8.4 \%$ difference ( $T=-2.31, P=0.033)$. c, Comparison of Sphagnum-dominated and shrubby peatland GWP (in $\left.\mathrm{CO}_{2} \mathrm{e}\right)$ over $5 \mathrm{yr}(100 \%, T=3.07, P=0.037)$. Pristine sites were dominated by Sphagnum species and Juncus effusus ( $80 \%$ and $20 \%$, respectively), while the drained site was of mixed composition (grass species $30 \%$, Polytrichum commune 20\%, Sphagnum species 20\%, shrubs 20\%, bare peat $10 \%$ ). Negative fluxes represent uptake from the atmosphere. Five in situ sampling stations were used per peatland type; error bars denote SEM.

cells), bacillus (rod-shaped cells) and spirochaetes (spiral-shaped cells)); Supplementary Table 2 and Supplementary Text 3).

The effect of wood additions was most pronounced under drought conditions for most enzymes (Supplementary Table 2), and this could relate to the fact that phenolic compound oxidation increases enzyme inhibition, by both higher molecular weight substances (such as tannic acid, that is, polyphenolics) and lower molecular weight phenols (present in the peat as intermediates from polyphenolic degradation, for example, catechol, protocatechuic acid or caffeic acid ${ }^{32}$ ). This has been attributed to oxidized phenols reacting with an enzyme's sulfhydryl groups to form covalent linkages and/or oxidative polymerization, causing an increase in molecular weight, thereby enhancing protein binding through non-covalent bonds. Indeed, the higher the molecular weight, the more inhibitory phenolic compounds are found to be in peatlands ${ }^{34}$. The latter would also explain the greater effect on DON concentrations and iron scavenging, with both mechanisms having knock-on effects for nutrient acquisition and bacterial growth and proliferation (Supplementary Table 2). New evidence ${ }^{37}$ also suggests that drought causes the oxidation of soluble $\mathrm{Fe}^{2+}$ to less-soluble $\mathrm{Fe}^{3+}$ and that this may reduce activities of both oxidative and hydrolytic enzymes, thereby counteracting the 'enzymic latch' and enhancing Q10 carbon preservation ${ }^{38}$.

Similar effects were found using in vitro leachate additions from a suite of wood types and tannic acid (Supplementary Table 3 and Supplementary Text 3). However, more research is needed on their potential as a substitute for wood amendments.

\section{Carbon sequestration and ecosystem restoration applications}

Taken together, our results suggest that forest carbon capture combined with peatland storage could improve protection of host ecosystem soil carbon stock, even during drought. We attribute this to the extra polyphenols that wood releases and their quadruple lock on decomposition. However, while the results appear to hold across the UK peatlands and small-scale incubations here, demonstrating scalability via large-scale studies across a latitudinal gradient would be prudent before considering these mechanisms in geoengineering strategies.

Geoengineering pristine systems (for example, Sphagnum peatlands covering 3.8 million-4.1 million $\mathrm{km}$ (refs. ${ }^{22,39}$ ), Supplementary Text 4) would be controversial, and the economic and carbon costs of upscaling the strategies described here (for example, transporting and inserting supplements) may be prohibitive in remote locations. However, degraded sites are extensive and inherently more accessible; globally, $15 \%\left(500,000 \mathrm{~km}^{2}\right)$ are considered degraded (50.9 Mha) (ref. ${ }^{20}$ ) and $80,000 \mathrm{~km}^{2}$ are drained ${ }^{40}$. Leifeld and Menichetti ${ }^{20}$ called for mitigation via peatland rehabilitation because emissions could be reduced by $0.3-3.4 \mathrm{GtCO}_{2} \mathrm{e}$ while using 3.4 times less nitrogen and a smaller land area than other techniques. Our data suggest that drained and rewetted peat behaves similarly to pristine peat and could, therefore, be supplemented to save double this (Supplementary Table 4). Peatland restoration combined with supplementation could thus re-establish and enhance ecosystem function. We propose that restoration and conservation policymak- 
ers consider supplementation because peatland rewetting alone can cause increased $\mathrm{GHG}^{41}$ and nutrient release ${ }^{42}$, representing a eutrophication risk for receiving aquatic systems.

The evidence from boreal ${ }^{14}$ and temperate peatlands studied here suggests that wood supplementation may harness natural ecosystem drought-resistance mechanisms and warrants research as an approach to offset rising $\mathrm{CO}_{2}$ that does not risk collateral damage ${ }^{43}$. However, it also offers a potential route to stabilization of carbon stores via ecological engineering, whereby shrub and tree encroachment is encouraged (for example, by planting, herbivore exclusion or water table management), to create droughtresistant ecosystems. This would also circumvent the need to transport supplements and the disturbance due to wood insertion (Supplementary text 4). Indeed, where sufficient nutrients are available to sustain woody vegetation, natural succession will often occur from Sphagnum-dominated mire to shrubby and wooded heath communities ${ }^{42}$, and with climate change, arboreal peatlands are likely to expand ${ }^{28}$.

We propose the following priorities to understand whether these approaches could be upscaled: (1) screening wood types for optimal carbon sequestration and ecosystem soil carbon protection, (2) determining whether supplements can protect against droughts across temporal and spatial scales and across peatland types, (3) investigating the viability of supplementation across terrain types and (4) researching the potential for using industrial polyphenolic waste products. Furthermore, given the extent of drained peat and increasing demand for food and energy, both geological and ecological approaches probably need to be embedded into strategies that sustainably use and profit from restored peatlands by encouraging peat formation and production of renewable resources, that is, 'paludiculture' (including crops for food, construction and energy ${ }^{40,42,44,45}$ ). Thus, we encourage research into 'geo-paludiculture' (Supplementary Text 4), which may hold potential for harnessing natural resilience mechanisms in waterlogged agriculture ${ }^{20,40,42-44}$.

\section{Online content}

Any methods, additional references, Nature Research reporting summaries, source data, extended data, supplementary information, acknowledgements, peer review information; details of author contributions and competing interests; and statements of data and code availability are available at https://doi.org/10.1038/s41558020-0727-y.

Received: 12 March 2019; Accepted: 10 February 2020; 2.

\section{References}

1. Gorham, E. Northern peatlands: role in the carbon cycle and probable responses to climatic warming. Ecol. Appl. 1, 182-195 (1991).

2. Limpens, J. et al. Peatlands and the carbon cycle: from local processes to global implications-a synthesis. Biogeosciences 5, 1475-1491 (2008).

3. Holden, J. Peatland hydrology and carbon release: why small-scale process matters. Phil. Trans. R. Soc. Lond. A 363, 2891-2913 (2005).

4. Bonan, G. B. Forests and climate change: forcings, feedbacks, and the climate benefits of forests. Science 320, 1444-1449 (2008).

5. Depro, B. M., Murray, B. C., Alig, R. J. \& Shanks, A. Public land, timber harvests, and climate mitigation: quantifying carbon sequestration potential on US public timberlands. Ecol. Manag. 255, 1122-1134 (2008).

6. Pan, Y. et al. A large and persistent carbon sink in the world's forests. Science 333, 988-993 (2011).

7. IPCC Climate Change 2014: Impacts, Adaptation, and Vulnerability (eds Field, C. B. et al.) (Cambridge Univ. Press, 2014).

8. Korner, C. Slow in, rapid out-carbon flux studies and Kyoto targets. Science 300, 1242-1243 (2003).

9. Freeman, C., Ostle, N. \& Kang, H. An enzymic latch on a global carbon store. Nature 409, 149 (2001).

10. Laiho, R. Decomposition in peatlands: reconciling seemingly contrasting results on the impacts of lowered water levels. Soil Biol. Biochem. 38, 2011-2024 (2006).
11. Fenner, N. \& Freeman, C. Drought-induced carbon loss in peatlands. Nat. Geosci. 4, 895-900 (2011).

12. Freeman, C., Fenner, N. \& Shirsat, A. H. Peatland geoengineering: an alternative approach to terrestrial carbon sequestration. Phil. Trans. R. Soc. Lond. A 370, 4404-4421 (2012).

13. Fenner, N., Freeman, C. \& Reynolds, B. Hydrological effects on the diversity of phenolic degrading bacteria in a peatland: implications for carbon cycling. Soil Biol. Biochem. 37, 1277-1287 (2005).

14. Wang, H., Richardson, C. J. \& Ho, M. Dual controls on carbon loss during drought in peatlands. Nat. Clim. Change 5, 584-588 (2015).

15. Aloui, F., Ayadi, N., Charrier, F. \& Charrier, B. Durability of European oak (Quercus petraea and Quercus robur) against white rot fungi (Coriolus versicolor): relations with phenol extractives. Holz Roh Werkst. 62, 286-290 (2004).

16. Bragazza, L. et al. Atmospheric nitrogen deposition promotes carbon loss from peat bogs. Proc. Natl Acad. Sci. USA 103, 119386-119389 (2006).

17. Rasmussen, S., Wolff, C. \& Rudolph, H. Compartmentalization of phenolic constituents in Sphagnum. Phytochemistry 38, 35-39 (1995).

18. Painter, T. J. Lindow Man, Tollund Man and other peat-bog bodies: the preservative and antimicrobial action of sphagnan, a reactive glycuronoglycan with tanning and sequestering properties. Carbohydr. Polym. 15, 123-142 (1991)

19. Guyette, R. P., Dey, D. C. \& Stambaugh, M. C. The temporal distribution and carbon storage of large oak wood in streams and floodplain deposits. Ecosystems 11, 643-653 (2008).

20. Leifeld, J. \& Menichetti, L. The underappreciated potential of peatlands in global climate change mitigation strategies. Nat. Commun. 9, 1071 (2018).

21. Tian et al. The terrestrial biosphere as a net source of greenhouse gases to the atmosphere. Nature 531, 225-228 (2016).

22. Freeman, C. et al. Export of dissolved organic carbon from peatlands under elevated carbon dioxide levels. Nature 430, 195-198 (2004).

23. Goslan, E. H. et al. A comparison of disinfection by-products found in chlorinated and chloraminated drinking waters in Scotland. Water Res. 43, 4698-4706 (2009).

24. Freeman, C., Lock, M. A., Marxsen, J. \& Jones, S. E. Inhibitory effects of high molecular weight dissolved organic matter upon metabolic processes of biofilms from contrasting rivers and streams. Freshw. Biol. 24, 159-166 (1990).

25. Bonnett, S. A. F., Maltby, E. \& Freeman, C. Hydrological legacy determines the type of enzyme inhibition in a peatlands chronosequence. Sci. Rep. 7 , 9948 (2017).

26. Bragazza, L., Parisod, J., Buttler, A. \& Bardgett, R. D. Biogeochemical plant-soil microbe feedback in response to climate warming in peatlands. Nat. Clim. Change 3, 273-277 (2012).

27. Dise, N. Environmental science. Peatland response to global change. Science 326, 810-811 (2009)

28. Laiho et al. Scots pine litter decomposition along drainage succession and soil nutrient gradients in peatland forests, and the effects of inter-annual weather variation. Soil Biol. Biochem. 36, 1095-1109 (2004).

29. Williams, C. J., Shingara, E. A. \& Yavitt, J. B. Wetlands 20, 416 (2000).

30. Barthelmes, A., Couwenberg, J. \& Joosten, H. Carbon sequestration in alder wood peat-a palaeo-ecological approach. In Proc. International Conference on Carbon in Peatlands (2010).

31. Dai, J. \& Mumper, R. J. Plant phenolics: extraction, analysis and their antioxidant and anticancer properties. Molecules 15, 7313-7352 (2010).

32. Scalbert, A. Antimicrobial properties of tannins. Phytochemistry 30, 3875-3883 (1991).

33. Wetzel, R. G. Gradient-dominated ecosystems-sources and regulatory functions of dissolved organic matter in freshwater ecosystems. Hydrobiologia 229, 181-198 (1992)

34. Dunn, C. \& Freeman, C. The role of molecular weight in the enzymeinhibiting effect of phenolics: the significance in peatland carbon sequestration. Ecol. Eng. 114, 162-166 (2018).

35. Jones, D. L. \& Kielland, K. Soil amino acid turnover dominates the nitrogen flux in permafrost-dominated taiga forest soils. Soil Biol. Biochem. 34, 209-219 (2002)

36. Van Bodegom, P. M., Broekman, R., Van Dijk, J., Bakker, C. \& Aerts, R Ferrous iron stimulates phenol oxidase activity and organic matter decomposition in waterlogged wetlands. Biogeochem 76, 69-83 (2005).

37. Wang, Y., Wang, H., He, J.-S. \& Feng, X. Iron-mediated soil carbon response to water-table decline in an alpine wetland. Nat. Commun. 8, 1-9 (2017).

38. Raftery, A. E., Zimmer, A., Frierson, D. M. W., Startz, R. \& Liu, P. Less than $2{ }^{\circ} \mathrm{C}$ warming by 2100 unlikely. Nat. Clim. Change 7, 637-641 (2017).

39. Charman, D. Peatlands and Environmental Change (Wiley, 2002).

40. Wichtmann, W. \& Joosten, H. Paludiculture: peat formation and renewable resources from rewetted peatlands. IMCG Newsl. 2007-3, 24-28 (2007).

41. Worrall, F., et al. A Review of Current Evidence on Carbon Fluxes and Greenhouse Gas Emissions from UK Peatland Report No. 442 (JNCC, 2011). 
42. Wichtmann, W. \& Schäfer, A. in Wetlands: Monitoring, Modelling and Management (eds Okruszko, T. et al.) (Taylor \& Francis, 2007).

43. Wigley, T. M. L. A. Combined mitigation/geoengineering approach to climate stabilization. Science 314, 452-454 (2006).

44. Schröder, C., Dahms, T., Paulitz, J., Wichtmann, W. \& Wichmann, S. Towards large-scale paludiculture: addressing the challenges of biomass harvesting in

Q23 wet and rewetted peatlands. Mires Peat 16, 1-18 (2015).
45. Prager, A., Barthelmes, A. \& Joosten, H. A touch of tropics in temperate mires: on Alder carrs and carbon cycles. Peatl. Int. 2006/2, 26-31 (2006).

Publisher's note Springer Nature remains neutral with regard to jurisdictional claims in published maps and institutional affiliations.

(c) The Author(s), under exclusive licence to Springer Nature Limited 2020 


\section{Methods}

Site descriptions. Site characteristics (Supplementary Table 1) are described by Fenner and Freeman ${ }^{11}$, but briefly, the ombrotrophic site (site 1) is represented by the upland Migneint bog complex and contains ombrotrophic areas fed only by rainfall with an acidic $\mathrm{pH}(4.0)$ and oligotrophic areas where the $\mathrm{pH}$ is slightly less acidic (4.2) due to water inputs from the surrounding land as well as rainfall. The water table is high (at the surface, that is, $0 \mathrm{~cm}$, to $5 \mathrm{~cm}$ below the surface of the peat). The vegetation is dominated by Sphagnum species (S. subnitens, $S$. capillifolium), and the peat type is hemist. Organic matter (OM) content is $99 \%$, and bulk density is $0.05 \mathrm{~g} \mathrm{~cm}^{-3}$. The oligotrophic peat (site 2) also has a high wate table $(0 \mathrm{~cm}$ on average) with an average $\mathrm{pH}$ of 4.8 . and is generally characterized by $S$. subnitens and J. effusus with a hemist texture, OM content of $95 \%$ and bulk density of $0.06 \mathrm{~g} \mathrm{~cm}^{-3}$. Mesotrophic peat was collected from a calcareous lowland fen (site 3 ) with a pH of $\sim 6.0$ and water table between 0 and $-10 \mathrm{~cm}$. Vegetation is diverse but dominated by J. acutiflorus and Festca rubra. The peat type is fibrist with an OM content of $94 \%$ and bulk density of $0.08 \mathrm{~g} \mathrm{~cm}^{-3}$. Eutrophic peat was collected from a minerotrophic riparian wetland (site 4) draining farmland in a U-shaped valley carved out by glaciers in the last Ice Age. The $\mathrm{pH}$ is 5.1, and the site is waterlogged (water table $0 \mathrm{~cm}$ ). Dominant vegetation is $S$. recurvum, J. effusus and Polytrichum species with additional macrophytes, and the peat is classified as fibrist. OM content is $90 \%$, and bulk density is $0.16 \mathrm{~g} \mathrm{~cm}^{-3}$.

Determining the stability of exogenous carbon in peat. To investigate the stability of wood (1) when inserted into peat compared with that exposed on the peat surface and (2) as a result of changes in redox potential of the peat during drought (anaerobic-aerobic-anaerobic sequence), we used a controlled in vitro microcosm approach $\left(50 \mathrm{~cm}^{3}\right)$. Peat was collected from the biologically active surface layer (acrotelm, site 1, Supplementary Table 1) and green vegetation removed, with the remaining peat being gently homogenized to ensure differences were due to treatment rather than pre-existing heterogeneity. Uniform wood pieces (poplar and oak: $10 \mathrm{~mm} \times 10 \mathrm{~mm} \times 2 \mathrm{~mm}, \sim 121 \mathrm{mg}$ dry weight; 10 units, $2 \mathrm{~cm}^{3}$ ) were soaked in site water and inserted $5 \mathrm{~cm}$ below the surface of the peat For the first experiment, peat was maintained under field conditions (anaerobic with the water table at the surface), and the total incubation time was $60 \mathrm{~d}^{46}$. For the second experiment, the incubation time was the same, but it included a $32 \mathrm{~d}$ aerobic phase after $14 \mathrm{~d}$. Intensive aeration was carried out using compressed air, manifold units with flow regulation valves and flexible air lines (autoclavable to allow sterilization) connected to a pipette tip with an inline sterilizing air filter (Millipore $0.2 \mu \mathrm{m}$, autoclavable). Oxygen saturation was calibrated using an inline flow metre (Whatman).

Mass loss was calculated according to equation (1), and for experiment 1, inserted versus exposed wood was compared. For experiment 2 , mass loss in control (waterlogged) microcosms versus the simulated drought microcosms was measured. To investigate the potential for temperature- or nutrient-mediated opening of the latch ${ }^{11}$, we added phenol oxidase weekly in a parallel test within experiment 2 :

$$
\text { Loss of mass in wood } \%=\left[\left(m_{0 \text { wood }} / m_{\mathrm{d} \text { wood }}\right) / m_{0 \text { wood }}\right] \times 100
$$

where $m_{0 \text { wood }}$ is the dry weight of the wood sample before incubation and $m_{\mathrm{d} \text { wood }}$ is the dry weight of the wood sample after incubation.

Investigations into durability and dosage were also carried out using standard tests. Dosage was investigated using 1, 5, 10 and 20 wood units (for example, 0.2, $\left.1,2,4 \mathrm{~cm}^{3}\right)$; it was found that low and intermediate doses (5-10 units of wood, $1-2 \mathrm{~cm}^{3}$ ) were generally optimal since disturbance effects begin to occur at high dosages. Standard timber durability tests were carried out at $25^{\circ} \mathrm{C}$ and $65 \%$ relative humidity ${ }^{15}$ to confirm timber durability ratings (mass loss $<6 \%$, very durable; $5 \%-11 \%$, durable; $10 \%-21 \%$, fairly durable; $>20 \%$, little durable; $>30 \%$,

213 non-durable). However, these rely on exposure to one fungal species (Coriolus versicolor) only, and wood degradation in waterlogged conditions is likely to be primarily due to bacteria ${ }^{13}$

Polyphenolic compounds were quantified colorimetrically at $750 \mathrm{~nm}$ on leachate water treated with alkali $\left(\mathrm{NaCO}_{3}\right)$ and Folin-Ciocaltaeu reagent ${ }^{47}$. Gases were collected using a closed chamber technique ${ }^{48}$ with $\mathrm{CO}_{2}, \mathrm{CH}_{4}$ and $\mathrm{N}_{2} \mathrm{O}$ concentrations analysed by gas chromatography (Varian model 450 gas chromatograph). Linearity of gas emissions was first determined by capping the in vitro systems, microcosms/mesocosms, or using chambers (in the case of in situ measurements) and removing gas samples after 0, 10, 20, 30, 60, 120, $240 \mathrm{~min}$. The slope of the regression $\left(R^{2}>0.99, P<0.01\right)$ between concentration and time and increase in concentration (above initial background concentrations) were used to estimate 'net' fluxes (accounting for photosynthesis). GWP was calculated ${ }^{14}$ by summing all gases converted to $\mathrm{CO}_{2} \mathrm{e}^{49}$ (see Statistics and calculations). Water content was determined gravimetrically. Plastic controls were included to account for any potential physical disturbance effects due to treatment but showed negligible contributions (for example, Supplementary Fig. 3).

Effects of peat type on exogenous carbon stability. Intact plant-peat monoliths in $11 \mathrm{~cm} \times 40 \mathrm{~cm}$ deep $\left(3,802 \mathrm{~cm}^{3}\right)$ mesocosms were collected from sites 1-4. Monoliths were maintained under natural conditions (outdoor research compound) using site water. Severe drought manipulations involved water table lowering over $14 \mathrm{~d}$ to $30 \mathrm{~cm}$ (maximum) below the surface, followed by $60 \mathrm{~d}$ drought and $14 \mathrm{~d}$ rewet phases, mimicking the 2006 severe natural drought (1 in $100 \mathrm{yr}$ ) effects monitored in the field (natural laboratory), following $2 \mathrm{yr}$ of waterlogged conditions (depth to water table $0-5 \mathrm{~cm}$ ). Ten poplar wood pieces $\left(160 \mathrm{~mm} \times 40 \mathrm{~mm} \times 3 \mathrm{~mm} ; 11 \mathrm{~g}\right.$ dry weight; $\left.192 \mathrm{~cm}^{3}\right)$ were inserted vertically to $5 \mathrm{~cm}$ depth in the plant-peat monoliths, and mass loss and so on were determined as in the preceding.

Leachate DOC and DON were analysed using a total organic $\mathrm{C}$ analyser (Thermalox, Analytical Sciences). Isotopic signatures $\left(\delta^{13} \mathrm{C}\right.$ and $\left.\delta^{15} \mathrm{~N}\right)$ were determined using an isotope ratio mass spectrometer (Hydra 20/20, SerCon) with solid (elemental analyser, Costech Instruments) and trace gas (gas chromatograph, SerCon) interfaces. Liquids (pore water or leachate for DOC and DON analysis) were first adsorbed to chromosorb (W 30-60 mesh acid washed, SerCon) and analysed as solids.

Pre-aged oak. Natural fallen oak (Quercus robur $>5 \mathrm{yr}$ on the surface of park grassland, Caernarfon, Wales) was inserted into mesocosms collected from site 3 (as in the preceding, Supplementary Table 1).

Hydrological legacy. The effects of hydrological legacy on exogenous carbon stability were studied using the 'natural laboratory', along with the effects of a natural shift from Sphagnum to woody shrubs as a result of drainage. The site consists of four flush wetlands in a discontinuous serial cascade located within a mire peatland system in the Upper Wye catchment (Cerrig-yr-Wyn subcatchment) on Plynlimon (mid-Wales, UK, National Grid reference SN 820 $866 ; 52^{\circ} 26^{\prime} \mathrm{N}, 3^{\circ} 55^{\prime} \mathrm{W}$ ), typical of many in the uplands of Wales. Different hydrological conditions can be applied to the various wetlands because of these discontinuities, giving a water table gradient (pristine waterlogged control $>$ experimental summer drought $>$ experimental rewetting $>$ drained control $^{11}$ ) plus associated areas of similar characteristics.

The upper pair (site 2, Supplementary Table 1) have a higher water table with an average $\mathrm{pH}$ of 4.8 in the pristine peatland (water table $0 \mathrm{~cm}$ on average) and 4.7 in the increased-drought-frequency peatland (water table $0 \mathrm{~cm}$ on average). The upper two wetlands are characterized by water tables at or near the surface for non-drought years but, for example, $-15 \mathrm{~cm}$ for the moderate drought of 1995 and $-30 \mathrm{~cm}$ for the severe drought of 2006 .

The lower pair (experimental rewetting and drained control) have lower water tables (generally ranging from $49 \mathrm{~cm}$ to $9 \mathrm{~cm}$ below the surface of the peat in the drained wetland and between $16 \mathrm{~cm}$ and $1 \mathrm{~cm}$ in the rewetted system) and are more acidic, $\mathrm{pH} 4.4$ and 4.5, respectively. Hydraulic recharge is from water sources deep within the peat profile rather than surface flow. During the flood year of 2000, the control water table ranged between -49 and $-7 \mathrm{~cm}$ and the experimental site between -18 and $0 \mathrm{~cm}$, while during the severe drought year of 2006 these figures were -71 to $-27 \mathrm{~cm}$ and -58 to $-11 \mathrm{~cm}$ in the control and rewetted wetlands, respectively.

The peat is generally characterized by J. effusus, J. acutiflorus and S. subnitens with a hemist texture, OM content of $95 \%$ and bulk density of $0.06 \mathrm{~g} \mathrm{~cm}^{-3}$. However, the lower pair are characterized by less Sphagnum cover and more vascular plant and shrub species (Erica tetralix and Calluna vulagris).

Mechanisms inhibiting decomposition. Polyphenolic concentrations, enzyme activities and growth rates were measured using routine techniques (Supplementary Information). All enzyme activities were measured at field temperature and $\mathrm{pH}$ using $1 \mathrm{~cm}^{3}$ of peat. Phenol oxidase activities were measured using dihydroxy phenylalanine (L-DOPA) as the substrate, and extracellular hydrolase activities were measured using fluorogenic methylumbelliferyl (MUF) substrates. The protocols followed are detailed by Fenner et $\mathrm{al}^{13}$. Briefly, $10 \mathrm{mM}$ L-DOPA (Merck) and a homogenate of $1 \mathrm{~cm}^{3}$ of peat per $2 \mathrm{ml}$ of ultrapure water was prepared using a low-intensity homogenizer (Stomacher, Seward Colworth, model 400). The homogenate was diluted $1 / 1$ with ultrapure water, and $1 \mathrm{ml}$ aliquots were transferred to $2.5 \mathrm{ml}$ centrifuge tubes. Then $1 \mathrm{ml} \mathrm{L}$-DOPA solution or ultrapure water (control) was added to each tube. The tubes were shaken and incubated at field temperature for 1 or $9 \mathrm{~min}$ followed by immediate centrifugation at $72,000 \mathrm{~g}$ for $5 \mathrm{~min}$. The absorbance was measured at $460 \mathrm{~nm}$ using a spectrophotometer. Original peat samples were dried to constant weight to determine the dry weight and OM content. Activity was expressed in terms of nanomoles 2,3-dihydroindole-5,6-quinone-2-carboxylate (diqc) $\mathrm{min}^{-1} \mathrm{~g}^{-1}$ peat. The difference in absorbance, as a result of the two incubation periods, was used to determine the rate of product formation. Intracellular phenol oxidase $(\mathrm{C} 23 \mathrm{O})$ activity was measured spectrophotometrically $(375 \mathrm{~nm})$ at $\mathrm{pH} 7.5 \mathrm{using}$ catechol as the substrate and detecting the product muconic semialdehyde $\mathrm{e}^{50}$.

Peat extracellular hydrolase activities were measured fluorimetrically ${ }^{51}: 2 \mathrm{ml}$ of Methylcellosolve (2-ethoxyethanol (ethylene glycol monoethyl ether) Merck) was used to pre-dissolve all substrates. Then $1 \mathrm{~cm}^{3}$ of peat was gently homogenized for $30 \mathrm{~s}$ with $1 \mathrm{ml}$ of ultrapure water. To $1 \mathrm{ml}$ of this peat slurry, $3.5 \mathrm{ml}$ of either $500 \mathrm{mM}$ MUF- $B-D$-glucoside, 1,000 mM MUF-phosphate or 1,000 mM MUFsulphate substrate solution (Merck) was added. These concentrations were above the concentration at which substrate availability limits activity but below the 
concentration at which substrate inhibition occurs. The samples were mixed and allowed to incubate for $1 \mathrm{~h}$ at field temperature, except for those peats where phosphatase was very active, in which case the incubation time was reduced to $45 \mathrm{~min}$. Samples $(1.5 \mathrm{ml})$ were then centrifuged at $72,000 \mathrm{~g}$ for $5 \mathrm{~min}$. A range of standard concentrations of MUF free acid (Merck), within the range of the peat activities, was made up in the sample matrix (that is, slurry incubated under identical conditions as those described in the preceding, except for the substrates). Saturation concentrations for the assay were established by varying concentrations of MUF substrate ( $0-4 \mathrm{mM}$ ) added to samples. A luminescence spectrometer (Perkin-Elmer LS50) was used to determine fluorescence, at $450 \mathrm{~nm}$ emission and $330 \mathrm{~nm}$ excitation (slit setting 1), immediately after centrifugation.

Bacterial growth rates were estimated using incorporation of ${ }^{3} \mathrm{H}$ into bacteria extractions from $1-3 \mathrm{~g}$ of peat ${ }^{11}$ and $40 \mathrm{ml}$ of ultrapure water according to ref. ${ }^{52}$. Extractions were performed on a shaker for $15 \mathrm{~min}$ using $40 \mathrm{ml}$ of ultrapure water. A sample of 1-3g was optimal (>75\% extraction efficiency). Washed glass wool was used to remove remaining floating organic debris following centrifugation to separate cells from organic matter. [Methyl- $\left.{ }^{3} \mathrm{H}\right] \mathrm{TdR}\left(925 \mathrm{GBq} \mathrm{mmol}^{-1}\right.$, Amersham) was added to $2 \mathrm{ml}$ of bacterial suspension, giving a final concentration of $100 \mathrm{nM}$. Zero-time controls were included to determine the level of non-specific labelling in each case. All samples were read on a Wallac (Winspectal 1414) scintillation counter.

'Follow-up' in vitro leachate and tannic acid additions. The effects of adding polyphenolics leached from the chips of poplar (Liriodendron tulipifera), oak (Quercus robur), alder (Alnus glutinosa) and black locust (Robinia pseudoacacia; very durable under waterlogged conditions ${ }^{53}$ ), sapele (Entandrophragma cylindricum; tropical African distribution) and tannic acid (across a range of concentrations; Merck) was investigated in vitro using peat from site 1 (Supplementary Table 1) to better understand potential mechanisms and viability for geoengineering techniques. Leachate was collected from wood chips incubated in ultrapure water for 12 months and added to $30 \mathrm{~cm}^{3}$ of peat in $50 \mathrm{~cm}^{3}$ microcosms. Tannic acid $\left(10 \mathrm{mgl}^{-1}\right.$, gallotannin, tannin, $\mathrm{MW}=1,701.20$, Merck) treatments used concentrations matched to that of the natural leachates measured from wood additions (Supplementary Table 4) and were chosen due to the considerable literature suggesting that tannic acid is primarily responsible for antimicrobial effects and because it is commercially available. Control microcosms consisted of ultrapure water added to peat. The focus was on $\mathrm{N}$ levels, since NAGase along with $\mathrm{N}_{2} \mathrm{O}$ showed the highest suppression, and iron, because phenol oxidases rely on it for their activity, with these enzymes being most affected (extracellular phenol oxidase and intracellular $\mathrm{C} 23 \mathrm{O}$ ).

'Knock-out' procedures, used to disentangle, for example, effects on preexisting extracellular enzyme activities compared with de novo synthesis (described in ref. ${ }^{11}$ ), confirmed that all four proposed mechanisms of antimicrobial activity and toxicity were likely to contribute to the properties conferred on the host peat and again were enhanced in under-oxygenation.

Statistics and calculations. Minitab (version 17) was used for all statistical investigations. Data were first tested for normality and equality of variance before paired $T$ tests, ANOVA or regression analysis was done. For in vitro work, averages for distinct periods were calculated, for example, aerobic phase or anaerobic phase for control versus wood treatment ${ }^{54}$. Similarly, for the mesocosms, averages for distinct periods were calculated, and paired $T$ tests were used. ANOVA (GLM; ANOVA) was used to determine whether supplements induced a significant effect at each trophic level overall or during the drought phase. Paired $T$ tests were used to determine significance at each trophic level, both overall and under drought conditions within trophic systems and across systems (that is, using all data with a comparison between treatments and control). Regression analysis using categorical predictor coding was used to investigate relationships between trophic level and determinands for control and wood-treated mesocosms, both overall and for the drought phase. GLM ANOVA with treatment and trophic level as the model was used to determine that interactions were additive rather than synergistic ${ }^{54}$.

For the hydrological legacy work, mesocosms $(n=5)$ taken from within each peatland type were used as replicates, and paired $T$ tests were used as in the preceding. The effect of treatment was confirmed at site 2 (Supplementary Table 1) in situ, as were the effects of shifts in vegetation as a result of drainage.

We adopted GHG emission factors from ref. ${ }^{49}$ by including $\mathrm{CO}_{2}, \mathrm{CH}_{4}$ and $\mathrm{N}_{2} \mathrm{O}$, but not DOC, due to the large uncertainty in downstream reactions. GWP 17 refers to the $100 \mathrm{yr}$ time horizon ${ }^{49}$. The saving in GWP of $0.9 \times 10^{15} \mathrm{~g} \mathrm{y}^{-1}$ to
$1.0 \times 10^{15} \mathrm{~g} \mathrm{y}^{-1} \mathrm{CO}_{2} \mathrm{e}$ was based on the in situ study (site 2, Supplementary Table 1). It was determined by summing the three GHG species (average over $3 \mathrm{yr}$ in $\mathrm{CO}_{2} \mathrm{e}$ ) expressed in $\mathrm{g} \mathrm{km}^{-2} \mathrm{y}^{-1}$ (that is, $9.41 \mathrm{E}+08$ and $4.57 \mathrm{E}+08$ for control and wood addition, respectively) then multiplying the saving in GWP (that is, the difference) by 3.8 million and 4.1 million to find the range depending on area of peatlands used (3.8 million $\mathrm{km}^{2}$ lower, 4.1 million $\mathrm{km}^{2}$ upper $)^{2,39}$ then assuming that half this area might be accessible for wood supplementation.

\section{Data availability}

The data that support the findings of this study are available from the corresponding author on request. Source data for Figs. 1-5 are included with the paper.

\section{Code availability}

The releyant code for this study is available from the corresponding author on request.

\section{References}

46. Yang, J. S., Nib, J. R., Yuana, H. L. \& Wang, E. Biodegradation of three different wood chips by Pseudomonas sp. PKE117. Int. Biodeterior. Biodegrad. 60, 90-95 (2007).

47. Box, J. D. Investigation of the Folin Ciocalteu reagent for determination of polyphenolic substances in natural waters. Water Res. 17, 511-525 (1983).

48. Freeman, C., Lock, M. A. \& Reynolds, B. Fluxes of carbon dioxide, methane and nitrous oxide from a Welsh peatland following simulation of water table draw-down: potential feed-back to climatic change. Biogeochemistry 19, 51-60 (1993).

49. IPCC 2013 Supplement to the 2006 IPCC Guidelines for National Greenhouse Gas Inventories: Wetlands (eds Hiraishi, T. et al.) (IPCC, 2014).

50. Chen, Y. P., Lopez-de-Victoria, G. \& Lovell, C. R. Utilization of aromatic compounds as carbon and energy sources during growth and $\mathrm{N}_{2}$-fixation by free-living nitrogen fixing bacteria. Arch. Microbiol. 159, 207-212 (1993).

51. Freeman, C., Ostle, N. J., Fenner, N. \& Kang, H. A regulatory role for phenol oxidase during decomposition in peatlands. Soil Biol. Biochem. 36, 1663-1667 (2004).

52. Ranneklev, S. B. \& Bååth, E. Temperature-driven adaptation of the bacterial community in peat measured by using thymidine and leucine incorporation. Appl. Environ. Microbiol. 67, 1116-1122 (2001).

53. Claessens, H., Oosterbaan, A., Savill, P. \& Rondeux, J. A review of the characteristics of black alder (Alnus glutinosa (L.) Gaertn.) and their implications for silvicultural practices. Forestry 83, 163-175 (2010).

54. Fenner, N. et al. Elevated $\mathrm{CO}_{2}$ effects on peatland plant community carbon dynamics and DOC production. Ecosystems 10, 635-647 (2007).

\section{Acknowledgements}

We are grateful to NERC, the Leverhulme Trust and the Royal Society for funding this research. Thanks also to S. Hughes of the Centre for Ecology and Hydrology for providing data and field assistance.

\section{Author contributions}

N.F and C.F. designed the study; N.F. conducted the research; N.F. analysed the data and wrote the manuscript with C.F.

\section{Competing interests}

The authors declare no competing interests.

\section{Additional information}

Supplementary information is available for this paper at https://doi.org/10.1038/ s41558-020-0727-y.

Correspondence and requests for materials should be addressed to N.F.

Peer review information Nature Climate Change thanks Tim Moore, Hongjun Wang and the other, anonymous, reviewer(s) for their contribution to the peer review of this work.

Reprints and permissions information is available at www.nature.com/reprints. 


\section{QUERY FORM}

\section{Nature Climate Change}

\begin{tabular}{|l|c|}
\hline Manuscript ID & [Art. Id: 727] \\
\hline Author & Nathalie Fenner \\
\hline
\end{tabular}

\section{AUTHOR:}

The following queries have arisen during the editing of your manuscript. Please answer by making the requisite corrections directly in the e.proofing tool rather than marking them up on the PDF. This will ensure that your corrections are incorporated accurately and that your paper is published as quickly as possible.

\begin{tabular}{|c|c|}
\hline Query No. & Nature of Query \\
\hline Q1: & Please note that affiliations have been re-numbered for sequential order. \\
\hline Q2: & $\begin{array}{l}\text { Please check your article carefully, coordinate with any co-authors and enter all final edits clearly in the eproof, } \\
\text { remembering to save frequently. Once corrections are submitted, we cannot routinely make further changes to } \\
\text { the article. }\end{array}$ \\
\hline Q3: & $\begin{array}{l}\text { Note that the eproof should be amended in only one browser window at any one time; otherwise changes will be } \\
\text { overwritten. }\end{array}$ \\
\hline Q4: & $\begin{array}{l}\text { Author surnames have been highlighted. Please check these carefully and adjust if the first name or surname } \\
\text { is marked up incorrectly. Note that changes here will affect indexing of your article in public repositories such } \\
\text { as PubMed. Also, carefully check the spelling and numbering of all author names and affiliations, and the cor- } \\
\text { responding email address(es). }\end{array}$ \\
\hline Q5: & $\begin{array}{l}\text { You cannot alter accepted Supplementary Information files except for critical changes to scientific content. If } \\
\text { you do resupply any files, please also provide a brief (but complete) list of changes. If these are not considered } \\
\text { scientific changes, any altered Supplementary files will not be used, only the originally accepted version will be } \\
\text { published. }\end{array}$ \\
\hline Q6: & $\begin{array}{l}\text { In the sentence beginning 'Our results suggest ...' please indicate whether 'extra soluble polyphenols' means } \\
\text { polyphenols that are particularly soluble (i.e., extra-soluble polyphenols) or soluble polyphenols that are extra } \\
\text { (i.e., additional soluble polyphenols). }\end{array}$ \\
\hline Q7: & $\begin{array}{l}\text { We reserve 'significant' and its derivatives for statistical significance. Please reword any remaining uses where } \\
\text { this is not the intended meaning. (See edits to the sentence beginning 'However, mass loss in the oligotrophic ...' } \\
\text { for the first such edit.) }\end{array}$ \\
\hline Q8: & $\begin{array}{l}\text { Is the heading 'Direct effects on microbial metabolism' meant to match the third of the mechanisms inhibiting } \\
\text { decomposition (direct inhibition of microbial metabolism)? If so, please make the appropriate change. }\end{array}$ \\
\hline Q9: & $\begin{array}{l}\text { In the sentence beginning 'These mechanisms are likely to be inextricably linked ...' the word 'They' has been } \\
\text { replaced by 'These mechanisms' for clarity. Please check and confirm. }\end{array}$ \\
\hline Q10: & $\begin{array}{l}\text { Reference } 38 \text { was not originally cited in text. Please confirm that the citation of this reference after the sentence } \\
\text { 'oxidative and hydrolytic enzymes, thereby counteracting the 'enzymic-latch' and enhancing carbon' is ok. }\end{array}$ \\
\hline Q11: & $\begin{array}{l}\text { In the sentence beginning 'However, degraded sites are extensive ...' please indicate what ' } 15 \% \text { ' refers to: } 15 \% \text { of } \\
\text { what? }\end{array}$ \\
\hline
\end{tabular}




\section{QUERY FORM}

\begin{tabular}{|l|c|}
\hline \multicolumn{2}{|c|}{ Nature Climate Change } \\
\hline Manuscript ID & [Art. Id: 727] \\
\hline Author & Nathalie Fenner \\
\hline
\end{tabular}

\section{AUTHOR:}

The following queries have arisen during the editing of your manuscript. Please answer by making the requisite corrections directly in the e.proofing tool rather than marking them up on the PDF. This will ensure that your corrections are incorporated accurately and that your paper is published as quickly as possible.

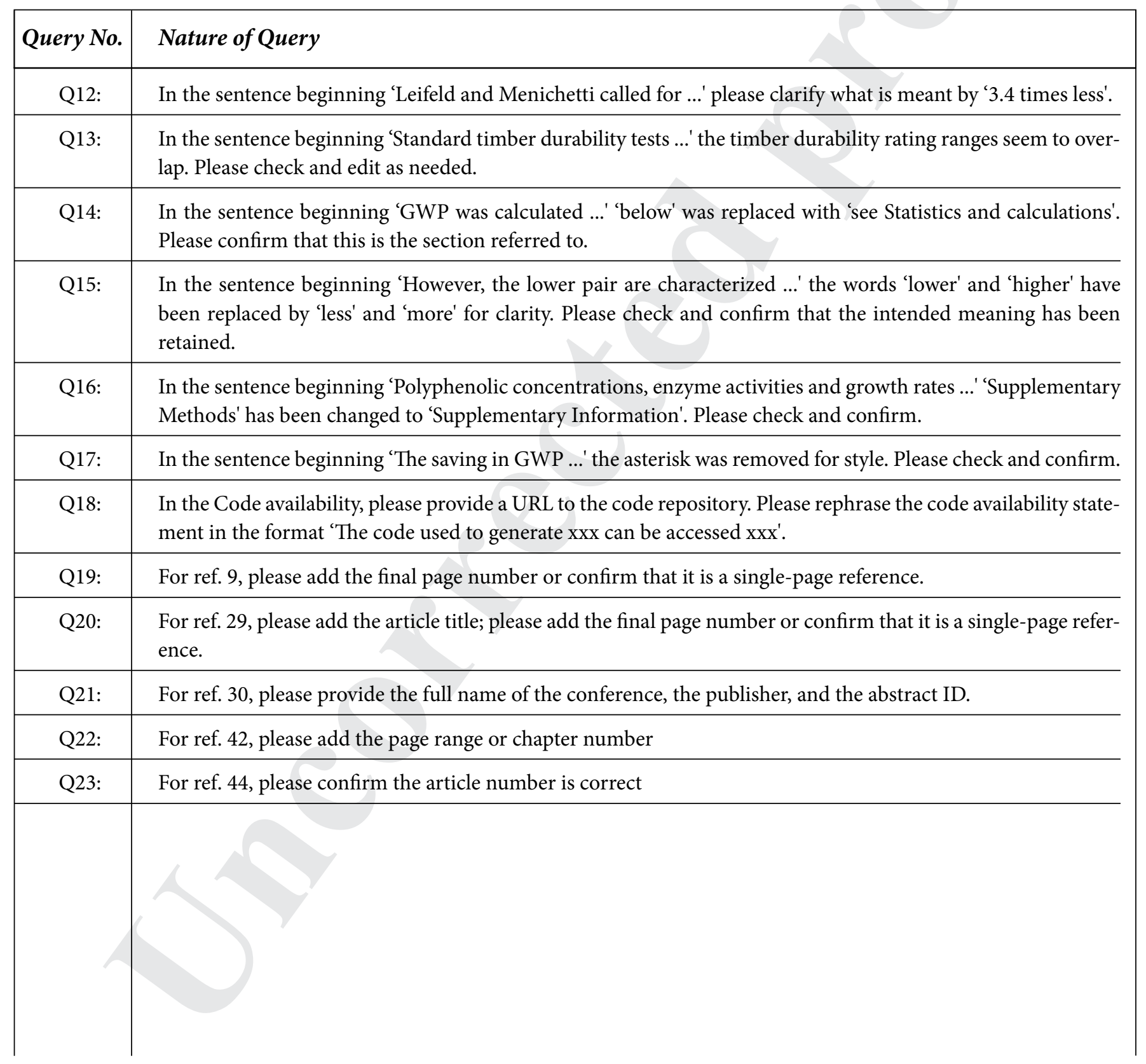

